Journal of Agricultural Sciences
(Tarim Bilimleri Dergisi)

\title{
Investigation of Tomato Ringspot Virus (ToRSV) by Real-Time TaqMan RT-PCR in Hakkari Province, Turkey
}

\author{
Nevin AKDURA ${ }^{\mathrm{a}^{*}} \mathbb{D}$, Murat ŞEVIK ${ }^{\mathrm{b}} \mathbb{D}$

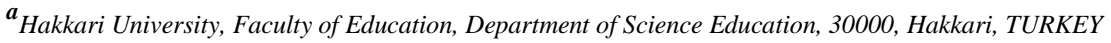

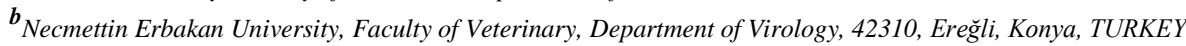

ARTICLE INFO

Research Article

Corresponding Author: Nevin AKDURA, E-mail: nevinakdura@hakkari.edu.tr

Received: 20 January 2020 / Revised 01 April 2020 / Accepted: 30 April 2020 / Online: 04 September 2021

\section{ABSTRACT}

Tomato ringspot virus (ToRSV) belongs to the Nepovirus genus in the family Secoviridae. It has a wide host range and is listed as a quarantine virus in Turkey. In this study, 80 leaf samples were collected from tomato, pepper, cucumber and grapevine cultivation sites located in three different parts of Hakkari province: Semdinli, Çukurca and Center districts. Real-time TaqMan reverse transcription-polymerase chain reaction (RT-PCR) method was used for the detection of the virus. Amplification was carried out in reaction mix including QuantiNova Probe RT-PCR kit (Qiagen, Germany) using primers and TaqMan probe based on 3'-UTR (untranslated region) of virus, which amplified a 182

Keywords: ToRSV, Molecular detection, Tomato, Pepper, Cucumber, Grapevine, Turkey bp product of the genome. ToRSV was detected in 13 of the 80 samples and threshold cycle (CT) values ranged from 23.9 to 37.4. It was found that $16.25 \%$ of the samples collected from the districts of Hakkari province were found to be infected with ToRSV whereas no ToRSV was detected in the samples collected from the center of the city. The virus was detected on pepper and cucumber samples in Çukurca district, and it was also detected in tomato, pepper, cucumber and grapevine samples in Şemdinli district. To our knowledge, this study is the first report of molecular detection of ToRSV by real-time TaqMan RT-PCR in Turkey.

\section{Introduction}

ToRSV (tomato ringspot virus, genus Nepovirus, subgroup C, family Secoviridae) is a bipartite single-stranded, positive sense RNA virus (Sanfaçon et al. 2006; 2009). ToRSV primarily infects perennial plants such as tomato (Lycopersicon esculentum Mill.), tobacco (Nicotiana tabacum), grapevine (Vitis vinifera), blueberry (Vaccinium corymbosum), strawberry (Fragaria vesca), geranium (Pelargonium domesticum), raspberry (Rubus idaeus), blackberry (Rubus fruticosus, Rubus sp), walnut (Juglans regia) and ornamental plants and causing diseases that results in great economic losses. Experimental host diversity of ToRSV is also very high and about 35 families are susceptible to this virus (Samuitiene et al. 2003; OEPP/EPPO 2005; Fuchs et al. 2010; Sneideris et al. 2012; Tzanetakis \& Martin 2013; Zindovic et al. 2014). The most typical symptom of ToRSV infection in plants is the presence of annular spots on the leaves. It has also other conspicuous symptoms in fruit trees and grapevines. In the grapevines, the virus manifests itself especially with necrotic pitting, spongy phloem tissue, fall of fruit, the rosette formation of leaves, ring spots on the leaves and general decrease in yield (OEPP/EPPO 2013). In infected plants, the effect of the virus can be seen as, pale yellow and pale green spots on the leaves that develop along the major side veins or the main vein of the leaves and causing systemic chlorotic or necrotic ring stains and deformation as well as inhibition of the fruit growth. In certain cases the virus does not show any visible symptoms, being usually characterized by a decrease in the yield. ToRSV is transmitted by natural ways, such as seeds, transplantation, pollen, vegetative organs and different species of Xiphinema (Bitterlin et al. 1987; Pinkerton et al. 2008).

The objective of this research is to determine the presence of ToRSV in tomato (Solanum lycopersicum), pepper (Capsicum annuит), cucumber (Cucumis sativus) and grapevine (Vitis vinifera) samples,collected from three different districts of Hakkari province, by real-time TaqMan RT-PCR method.

\section{Material and Methods}

\subsection{Field surveys and sample collection}

In early autumn of 2014 and summer of 2015, 80 leaf samples of tomato, pepper, cucumber and grapevine plants were collected from Çukurca, Şemdinli and Center districts of Hakkari province (Durankaya, Kırıkdağ, Üzümcü, Çimenli, Geçitli 
villages in the Center; Narlı, Geçimli, Kayalı villages in Çukurca; Bağlar, Şapatan, Güzelkonak, Yukarıyokuş, Balova villages in Şemdinli district). The samples were collected from various plant species based on the presence of suspicious viral symptoms at the time of sampling, such as necrosis, chlorosis, mosaic, and ring stains and transported to the laboratory in cool conditions and stored at $4{ }^{\circ} \mathrm{C}$ until tested.

\subsection{Preparation of primers and total nucleic acid extraction}

A pair of primers and probe were synthesized to amplify the 182-bp region in 3'-UTR of ToRSV RNA1 genome and used at the real-time TaqMan RT-PCR method (Table 1). RNA extraction from leaf samples of tomato, pepper, cucumber and grapevine were conducted by using the RNeasy Plant Mini Kit (Qiagen GmbH, Hilden, Germany) as specified in the manufacturer's protocol. Total nucleic acids were extracted from 80 samples and tested for the presence of ToRSV along with positive and negative controls.

Table 1- List of primers and probe used for detecting ToRSV

\begin{tabular}{llllc}
\hline Primer/Probe & & \multicolumn{1}{c}{ Sequence } & Target gene and position & Reference \\
\hline $\begin{array}{l}\text { ToRSV-UTR } \\
\text { (Forward primer) }\end{array}$ & F & 5'-GAATGGTTCCCAGCCACTT-3' & 3'-UTR 7686-7704 bp of RNA1 & Tang et al. \\
$\begin{array}{l}\text { ToRSV-UTR } \\
\text { (Reverse primer) }\end{array}$ & $\mathrm{R}$ & 5'-AGTCTCAACTTAACATACCAC-3' & 3'-UTR 7847-7867 bp of RNA1 & 2014 \\
$\begin{array}{l}\text { ToRSV-UTR } \\
\text { (Probe) }\end{array}$ & P & FAM-5'-AGGATCGC- & & \\
\hline
\end{tabular}

\subsection{The real-time TaqMan RT-PCR}

The 3'-UTR sequence of RNA1 genome of ToRSV was amplified by real-time TaqMan RT-PCR method. Positive control was used to obtain high accuracy and optimization in real-time TaqMan RT-PCR. The plant sample (the original host: Pelargonium sp) obtained from Leibniz-Institut DSMZ German Collection of Microorganisms and Cell Cultures (Germany) was used as positive control. Nuclease-free water was used as negative control. The total RT-PCR reaction mix was prepared by using QuantiFast Probe PCR (Qiagen, Germany) and it consisted of $1 \mu \mathrm{l}$ forward primer $(0.3 \mu \mathrm{M}), 1 \mu 1$ reverse primer $(0.3 \mu \mathrm{M}), 1 \mu \mathrm{l}$ prob $(0.5 \mu \mathrm{M}), 10 \mu \mathrm{l} 2$ xProbe RT-PCR Mix, $0.2 \mu \mathrm{l}$ QuantiFast RT Mix, $4.4 \mu \mathrm{l} \mathrm{MgCI} 2(5.5 \mu \mathrm{M})$ and $1.4 \mu \mathrm{l}$ Rase-free water. 5 $\mu \mathrm{l}$ of RNA isolated from leaf samples was added to the mix, amounting a total of $20 \mu \mathrm{l}$. For amplification, complementary DNA (cDNA) was synthesized at $50{ }^{\circ} \mathrm{C}$ for $10 \mathrm{~min}$, initial denaturation was conducted at $95{ }^{\circ} \mathrm{C}$ for 5 min and amplification step were performed in a total of 40 cycles at $95{ }^{\circ} \mathrm{C}$ for $15 \mathrm{~min}$, and at $60{ }^{\circ} \mathrm{C}$ for $45 \mathrm{sec}$. Real time RT-PCR analyses were performed using Rotor-Gene Q (Qiagen, Germany) and Rotor Gene Q Series Software (version 2.3.1).

\section{Results and Discussion}

\subsection{Field observation}

Field surveys were conducted in Çukurca, Şemdinli and Center districts of Hakkari province during the 2014-2015 growing season. It was observed during the surveys that vegetable farming is generally done without the use of pesticide in these areas and so that plants are susceptible to viral and other infectious agents such as bacteria, fungi etc. The samples were collected in accordance with the common symptoms that are known to be caused by ToRSV on tomato, pepper, cucumber and grapevine (Figure 1). The plants showing no apparent known symptoms were also sampled for control. Eighty samples were collected from 13 villages in study area (Table 2).

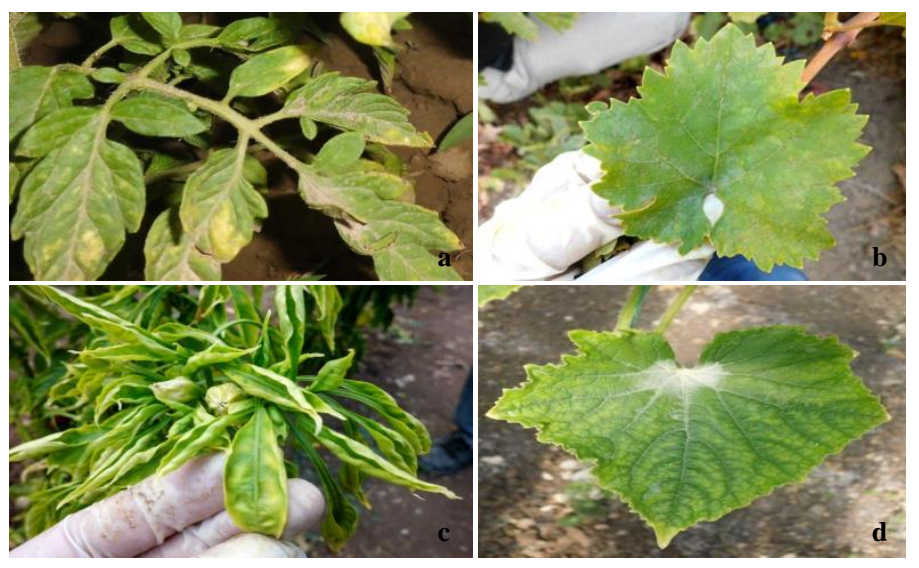

Figure 1- Symptomatic plants collected in the field survey from Hakkari province: a) Tomato b) Grapevine c) Pepper d) Cucumber 
Table 2- List of plant samples collected from Hakkari province for real-time TaqMan RT-PCR analyses

\begin{tabular}{|c|c|c|c|c|c|}
\hline No & Host & Location & No & Host & Location \\
\hline 1 & Tomato & Çukurca-Narlı & 41 & Cucumber & Şemdinli-Balova \\
\hline 2 & Tomato & Çukurca-Narlı & 42 & Grapevine & Şemdinli-Bağlar \\
\hline 3 & Tomato & Çukurca- Narlı & 43 & Grapevine & Şemdinli-Bağlar \\
\hline 4 & Tomato & Çukurca-Narlı & 44 & Grapevine & Şemdinli-Bağlar \\
\hline 5 & Tomato & Çukurca-Geçimli & 45 & Grapevine & Şemdinli-Şapatan \\
\hline 6 & Tomato & Çukurca-Geçimli & 46 & Grapevine & Şemdinli-Şapatan \\
\hline 7 & Tomato & Çukurca-Kayalı & 47 & Grapevine & Şemdinli-Şapatan \\
\hline 8 & Tomato & Çukurca-Kayalı & 48 & Grapevine & Şemdinli-Yukarıyokuş \\
\hline 9 & Pepper & Çukurca-Narlı & 49 & Grapevine & Şemdinli-Yukarıyokuş \\
\hline 10 & Pepper & Çukurca-Narlı & 50 & Grapevine & Şemdinli-Yukarıyokuş \\
\hline 11 & Pepper & Çukurca-Geçimli & 51 & Grapevine & Şemdinli-Yukarıyokuş \\
\hline 12 & Pepper & Çukurca- Geçimli & 52 & Grapevine & Şemdinli-Yukarıyokuş \\
\hline 13 & Pepper & Çukurca-Narlı & 53 & Grapevine & Şemdinli-Yukarıyokuş \\
\hline 14 & Pepper & Çukurca-Narlı & 54 & Grapevine & Şemdinli-Şapatan \\
\hline 15 & Pepper & Çukurca-Narlı & 55 & Grapevine & Şemdinli-Şapatan \\
\hline 16 & Pepper & Çukurca-Narlı & 56 & Grapevine & Şemdinli-Şapatan \\
\hline 17 & Cucumber & Çukurca-Narlı & 57 & Cucumber & Şemdinli-Güzelkonak \\
\hline 18 & Cucumber & Çukurca-Narlı & 58 & Cucumber & Şemdinli-Güzelkonak \\
\hline 19 & Cucumber & Çukurca-Kayalı & 59 & Cucumber & Şemdinli-Güzelkonak \\
\hline 20 & Cucumber & Çukurca-Kayalı & 60 & Tomato & Center-Durankaya \\
\hline 21 & Tomato & Şemdinli-Balova & 61 & Tomato & Center-Durankaya \\
\hline 22 & Tomato & Şemdinli-Balova & 62 & Tomato & Center-Durankaya \\
\hline 23 & Tomato & Şemdinli-Güzelkonak & 63 & Tomato & Center-Durankaya \\
\hline 24 & Tomato & Şemdinli-Güzelkonak & 64 & Tomato & Center-Durankaya \\
\hline 25 & Tomato & Şemdinli-Güzelkonak & 65 & Tomato & Center-Durankaya \\
\hline 26 & Tomato & Şemdinli-Yukarıyokuş & 66 & Tomato & Center-Durankaya \\
\hline 27 & Tomato & Şemdinli-Yukarıyokuş & 67 & Pepper & Center-Durankaya \\
\hline 28 & Tomato & Şemdinli-Yukarıyokuş & 68 & Pepper & Center-Durankaya \\
\hline 29 & Pepper & Şemdinli-Güzelkonak & 69 & Pepper & Center-Durankaya \\
\hline 30 & Pepper & Şemdinli-Güzelkonak & 70 & Pepper & Center-Durankaya \\
\hline 31 & Pepper & Şemdinli-Güzelkonak & 71 & Tomato & Center-Üzümcü \\
\hline 32 & Pepper & Şemdinli-Balova & 72 & Tomato & Center-Üzümcü \\
\hline 33 & Pepper & Şemdinli-Balova & 73 & Grapevine & Çukurca-Narlı \\
\hline 34 & Pepper & Şemdinli-Balova & 74 & Cucumber & Center-Kırıkdağ \\
\hline 35 & Pepper & Şemdinli-Balova & 75 & Cucumber & Center-Kırıkdağ \\
\hline 36 & Pepper & Şemdinli-Balova & 76 & Pepper & Center-Kırıkdağ \\
\hline 37 & Cucumber & Şemdinli-Balova & 77 & Pepper & Center-Kırıkdağ \\
\hline 38 & Cucumber & Şemdinli-Balova & 78 & Cucumber & Center-Çimenli \\
\hline 39 & Cucumber & Şemdinli-Balova & 79 & Grapevine & Center-Çimenli \\
\hline 40 & Cucumber & Şemdinli-Balova & 80 & Cucumber & Center-Geçitli \\
\hline
\end{tabular}

\subsection{Molecular detection}

The CT value of the positive control was 15.6. After determining the appropriate program for real-time TaqMan RT-PCR with the positive control, the procedure was applied to the other samples. After the tests for optimization, a total of 80 samples were evaluated by real-time TaqMan RT-PCR. The real-time TaqMan RT-PCR tests conclusively proved the presence of ToRSV in the province. Real-time TaqMan RT-PCR analysis of 80 samples collected in the field surveys revealed that 13 (16.25\%) samples were infected with ToRSV. According to the real-time TaqMan RT-PCR results, CT value of ToRSV infected samples ranged from 23.88 to 37.41 (Table 3). Samples with CT value greater than 38 were ignored. 
Table 3- CT (cycle threshold) values obtained from real-time TaqMan RT-PCR analyses of different plant samples collected from Hakkari province

\begin{tabular}{lccc}
\hline The collected field & Host & $\begin{array}{c}\text { No of infected ToRSV the } \\
\text { sample }\end{array}$ & CT value \\
\hline Çukurca-Geçimli & Pepper & 12 & 33.49 \\
Çukurca-Kayalı & Cucumber & 20 & 35.99 \\
Şemdinli-Balova & Tomato & 21 & 32.66 \\
Şemdinli-Balova & Tomato & 22 & 34.09 \\
Şemdinli-Güzelkonak & Tomato & 24 & 30.9 \\
Şemdinli-Güzelkonak & Tomato & 25 & 37.29 \\
Şemdinli-Yukarıyokuş & Tomato & 26 & 33.49 \\
Şemdinli-Yukarıyokuş & Tomato & 27 & 37.41 \\
Şemdinli-Yukarıyokuş & Tomato & 28 & 32.48 \\
Şemdinli-Balova & Pepper & 34 & 34.96 \\
Şemdinli-Balova & Pepper & 35 & 37.04 \\
Şemdinli-Balova & Cucumber & 40 & 33.21 \\
Şemdinli-Şapatan & Grapevine & 54 & 23.88 \\
\hline
\end{tabular}

The data obtained showed that ToRSV incidence was highest in Şemdinli district (28.20\%) and lowest in Çukurca district $(10 \%)$. ToRSV was detected in the tested tomato, pepper, cucumber and grapevine samples. None of the samples collected from Center were found to be infected with the ToRSV (Table 4). The results showed that ToRSV can be found in various cultivation sites in Hakkari province, but the virus is not wide spread in Hakkari province.

Table 4- ToRSV infection rate in tomato, pepper, cucumber and grapevine samples collected from Hakkari province

\begin{tabular}{|c|c|c|c|c|c|c|}
\hline \multirow[b]{2}{*}{ Province } & \multirow[b]{2}{*}{ District } & \multicolumn{4}{|c|}{ Collected Samples -ToRSV Infected Samples } & \multirow{2}{*}{ Avarage infection rate $(\%)$} \\
\hline & & Tomato & Pepper & Cucumber & Grapevine & \\
\hline \multirow{3}{*}{ Hakkari } & Center & $9-0$ & $6-0$ & $4-0$ & $2-0$ & 0 \\
\hline & Çukurca & $8-0$ & $8-1$ & $4-1$ & $0-0$ & 10 \\
\hline & Şemdinli & $8-7$ & $11-2$ & $5-1$ & $15-1$ & 28.2 \\
\hline Total & & $25-7$ & $25-3$ & $13-2$ & $17-1$ & 16.25 \\
\hline
\end{tabular}

ToRSV is a virus with a very wide host range. The damage caused on plants by this virus has encouraged us to work on it. ToRSV spreading from North America to other parts of the world, is also reported from Netherlands, Chile, Australia, Iran (Samuitiene et al. 2003; Moini 2010; Sokhansanj et al. 2012; Rivera et al. 2016; Roberts et al. 2018).

Presence of ToRSV can be determined by biological indexing, serological and molecular methods. Mechanical inoculation to herbaceous plants is also applied and is known to be simple and reliable. On the other hand, biological indexing is a timeconsuming method and it requires considerable experience, meaning that only a limited number of plants can be tested by use of this method. Enzyme Linked Immunosorbent Assay (ELISA) and Double-Antibody Sandwich Enzyme Linked Immunosorbent Assay (DAS-ELISA) can be used for serological diagnosis of ToRSV. Moini (2010) detected ToRSV by ELISA method in the leaf samples collected from apples in the north-east region of Iran. The genome of most plant viruses consists of RNA. Detection of the RNA sequence by PCR requires some changes. Prior to the application of PCR, RNA must have a reverse copy called cDNA. The RT-PCR is a very sensitive method and there may be inhibition problems in the samples. It should also be noted that the use of this method requires experienced researchers (OEPP/EPPO 2005). Detection of ToRSV by RT-PCR has been developed for multiple strains of ToRSV in both herbaceous and woody plants (Griesbach 1995). Msikita (2007) compared ELISA with RT-PCR methods for ToRSV detection and preferred RT-PCR with the identified appropriate primary sequence. Digiaro et al. (2007) studied the development of degenerate and specific primers for differential and simultaneous RT-PCR detection between subgroups A, B and C of grape infecting nepoviruses. They were designed 
specifically for RNA-1 3'-UTR for grapevine and provided a source for studies on the determination of this factor in grapevine with obtained positive results. A real-time RT-PCR test has been developed for rapid and sensitive detection of ToRSV. Stewart et al. (2007) tested samples for ToRSV primarily by ELISA. Real-time RT-PCR detection of ToRSV was performed in host tissues and a comparison was made between real-time PCR and ELISA. It was concluded that the results obtained by realtime PCR were more sensitive than ELISA. It was also seen that the samples that did not show positive results by ELISA were positive when tested in much lower amounts by real-time RT-PCR. Osman et al. (2008) compared low-density sequences using real-time TaqMan PCR and RT-PCR in the detection of grapevine viruses and examined the reliability of the results for ToRSV. This was the first report on the use of low-density sequences in the detection of plant viruses. Tang et al. (2014) detected the presence of ToRSV on grapevine by targeting RNA-1 3'-UTR region by real-time Taqman RT-PCR. In terms of specificity, sensitivity and reliability in the detection of ToRSV, real-time TaqMan RT-PCR and other real-time RT-PCR methods were compared. The real-time TaqMan RT-PCR used in that study was designed for the highly conserved region of ToRSV 3'-UTR. The TaqMan real-time RT-PCR test showed that the method can be widely used in the overall detection of ToRSV over a wide range of hosts and it also served as a resource for the method used in our research.

\section{Conclusions}

The presence of ToRSV in Turkey has been reported in tomato, pepper, cucumber (Fidan 1995; Arl1-Sökmen \& Şevik 2006), stone fruit (Azeri \& Çiçek 1997), blackberry (Sertkaya 2010) and strawberry (Yeşilçöllü et al. 2011). The methods used in these studies were ELISA and RT-PCR. In the studies where the primary method was real-time RT-PCR, grapevine was preferred as a host for detection of ToRSV. In this study, we detected the presence of ToRSV in different hosts. Samples with CT values $\leq 38$ were accepted infected with ToRSV. CT value of the positive control was found to be 15.6 , but CT value of the other samples that were considered positive was higher. CT values increased as the density of the virus decreased in the samples. This may have stemmed from the evaluation of different hosts. In the survey, ToRSV was detected in tomato, pepper, cucumber and grapevine in Şemdinli district and in pepper and cucumber in Çukurca of Hakkari province. Of the 80 samples, $13(16.25 \%)$ samples were found to be infected with ToRSV and it is good to note that areas infected with ToRSV are uncommon. ToRSV-infected plants are concentrated mostly in Şemdinli. It is noteworthy that the uncommon use of pesticides and the use of local seeds in the fields observed are widespread. ToRSV can be transmitted by mechanically, nematode vectors, seeds and pollen in some plants, therefore it will be appropriate to comply with the internal quarantine rules. Although there have been a number of attempts to identify the presence of ToRSV in Turkey, this study is the first report of molecular detection of ToRSV in different hosts by real-time TaqMan RT-PCR.

\section{Acknowledgements}

The study was supported by a grant from Scientific Research Projects Unit of Hakkari University (Project no: EF2015BAP4). We are grateful to Dr. Stephan Winter, Dr. Wulf Menzel (Leibniz Institute, DSMZ, Germany) and Dr. Farshad Rakhshandehroo (Islamic Azad University, Tehran, Iran) for providing us ToRSV isolate as positive control and support.

\section{References}

Arl1-Sökmen M \& Şevik M A (2006). Viruses infecting field-grown tomatoes in Samsun province. Archives of Phytopathology and Plant Protection 39(4): 283-288 https://doi.org/10.1080/03235400500222057

Azeri T \& Çiçek Y (1997). Detection of virus diseases affecting almond nursery trees in western Anatolia (Turkey). EPPO Bulletin 27(4): 547-550 https://doi.org/10.1111/j.1365-2338.1997.tb00682.x

Bitterlin M W, Gonsalves D \& Scorza R (1987). Improved mechanical transmission of tomato ringspot virus to Prunus seedlings. Phytopathology 77: 560-563 https://doi.org/10.1094/phyto-77-560

Digiaro M, Elbeaino T \& Martelli G P (2007). Development of degenerate and species-specific primers for the differential and simultaneous RT-PCR detection of grapevine-infecting nepoviruses of subgroups A, B and C. Journal of Virological Methods 141(1): 34-40 https://doi.org/10.1016/j.jviromet.2006.11.033

Fidan Ü (1995). Virus diseases of vegetables in greenhouses in İzmir and Muğla. Journal of Turkish Phytopathology 24(1): 7-14

Fuchs M, Abawi G S, Marsella-Herrick P, Cox R, Cox K D, Carroll J E \& Martin R R (2010). Occurrence of tomato ringspot virus and tobacco ringspot virus in highbush blueberry in Newyork state. Journal of Plant Pathology 92(2): 451-459

Griesbach J A (1995). Detection of Tomato Ringspot virus by polymerase chain reaction. Plant Disease 79(10): 1054-1056 https://doi.org/10.1094/pd-79-1054

Moini A A (2010). Identification of Tomato ringspot virus (ToRSV) on apple in Iran. Australasian Plant Disease Notes 5: 105-106 https://doi.org/10.1071/dn10038

Msikita W (2007). Issues with Tomato Ringspot Virus (ToRSV) Detection, WERA 020 Annual Report 1-3

OEPP/EPPO (2005). Tomato ringspot nepovirus. Bulletin OEPP/EPPO Bulletin 35: 313-318 https://doi.org/10.1111/j.13652338.2005.00831.x

OEPP/EPPO (2013). Tomato ringspot virus in fruit trees and grapevine: inspection. Phytosanitary procedures. Bulletin OEPP/EPPO Bulletin 43(3): 397 https://doi.org/10.1111/epp.12073

Osman F, Leutenegger C, Golino D \& Rowhani A (2008). Comparison of low-density arrays, RT-PCR and real-time TaqMan® RT-PCR in detection of grapevine viruses. Journal of Virological Methods 149(2): 292-299 https://doi.org/10.1016/j.jviromet.2008.01.012

Pinkerton J N, Kraus J, Martin R R \& Schreiner R P (2008). Epidemiology of Xiphinema americanum and Tomato ringspot virus on red raspberry, Rubus idaeus. Plant Disease 92(3): 364-371 https://doi.org/10.1094/pdis-92-3-0364 
Rivera L, Zamorano A \& Fiore N (2016). Genetic divergence of tomato ringspot virus. Archives of Virology 161(5): 1395-1399 https://doi.org/10.1007/s00705-016-2775-1

Roberts J M K, Ireland K B, Tay W T \& Paini D (2018). Honey bee-assisted surveillance for early plant virus detection. Annals Applied Biology 173(3): 285-293 https://doi.org/10.1111/aab.12461

Samuitiene M, Zitikaite I, Navalinskiene M \& Valiunas D (2003). Identification of tomato ringspot nepovirus by RT-PCR. Biologija 4: 3538

Sanfaçon H, Zhang G, Chisholm J, Jafarpour B \& Jovel J (2006). In: Teixcira da Silva, J. (Ed.), Molecular Biology of Tomato Ringspot Nepovirus, a Pathogen of Ornamentals, Small Fruits and Fruit Trees. Global Science Books, London, pp. 540-546

Sanfaçon H, Wellink J, Le Gall O, Karasev A, van der Vlugt R \& Wetzel T (2009). Secoviridae: a proposed family of plant viruses within the order Picornavirales that combines the families Sequiviridae and Comoviridae, the unassigned genera Cheravirus and Sadwavirus, and the proposed genus Torradovirus. Archives of Virology 154(5): 899-907 https://doi.org/10.1007/s00705-009-0367-z

Sertkaya G (2010). Tomato ringspot nepovirus (ToRSV) in wild blackberry (Rubus fruticosus L.) in Hatay province of Turkey. Julius- Kühn Archiv (427): 201-203

Sneideris D, Zitikaite I, Zizyte M, Grigaliunaite B \& Staniulis J (2012). Identification of nepoviruses in tomato (Lycopersicon esculentum Mill.). Žemdirbyste =Agriculture 99(2): 173-178

Sokhansanj Y, Rakhshandehroo F \& Pourrahim R (2012). First Report of Tomato ringspot virus Infecting Pepper in Iran. Disease Notes 96(12): 1828 https://doi.org/10.1094/pdis-07-12-0664-pdn

Stewart E L, Qu X, Overton B E, Gildow F E, Wenner N G \& Grove D S (2007). Development of a real-time RT-PCR SYBR Green assay for Tomato ring spot virus in grape. Plant Diseases 91(9): 1083-1088 https://doi.org/10.1094/pdis-91-9-1083

Tang J, Khan S, Delmiglio C \& Ward L I (2014). Sensitive detection of Tomato ringspot virus by real-time TaqMan RT-PCR targeting the highly conserved 3-UTR region. Journal of Virological Methods 201: 38-43 https://doi.org/10.1016/j.jviromet.2014.02.011

Tzanetakis I E \& Martin R (2013). Expanding Field of Strawberry Viruses Which Are Important in North America. International Journal of Fruit Science 13(1-2): 184-195 https://doi.org/10.1080/15538362.2012.698164

Yeşilçöllü S, Gümüş M \& Paylan I C (2011). Studies on the Detection of Viruses in Strawberry Growing Areas in Aegean Region (In Turkish). The Journal of Turkish Phytopathology 40(1-3): 13-20

Zindovic J, Marn V M \& Plesko I M (2014). Phytosanitary status of grapevine in Montenegro. EPPO Bulletin 44(1): 60-64 https://doi.org/10.1111/epp.12084

C 2021 by the authors. Licensee Ankara University, Faculty of Agriculture, Ankara, Turkey.

This article is an open access article distributed under the terms and conditions of the Creative

Commons Attribution (CC BY) license (http://creativecommons.org/licenses/by/4.0/). 